\title{
Pengaruh Kompetensi dan Komunikasi Organisasi Terhadap Kinerja Melalui Kepuasan Kerja sebagai Variabel Intervening pada Pendamping PKH Kabupaten Kebumen
}

\author{
Anggun Palupining Tiyas ${ }^{1}$, Parmin ${ }^{2}$ \\ 1,2 Universitas Putra Bangsa \\ Email: anggunp030@gmail.com ${ }^{1}$
}

ARTICLE INFO

Article History:

Received: June 19th 2021

Accepted: June $21^{\text {st }} 2021$

Published: June 21 2021

Keywords:

Kompetensi, Komunikasi Organisasi, Kepuasan Kerja, Kinerja

\begin{abstract}
Penelitian ini bertujuan untuk menguji pengaruh kompetensi dan komunikasi organisasi terhadap kinerja melalui kepuasan kerja sebagai variabel intervening. Variabel dalam penelitian ini terdiri dari tiga jenis variabel, yaitu variabel bebas yang meliputi kompetensi dan komunikasi organisasi. Variabel terikat meliputi kinerja dan variabel intervening yaitu kepuasan kerja. Populasi dalam penelitian ini yaitu 247 orang sedangkan sampel dalam penelitian ini adalah pendamping $\mathrm{PKH}$ di Kabupaten Kebumen yang berjumlah 72 orang. Teknik pengambilan sampel adalah teknik probability sampling yakni simple random sampling yaitu mengambil sampel dari populasi dilakukan secara acak tanpa memperhatikan strata yang ada dalam populasi. Teknik pengumpulan data menggunakan kuesioner, analisis data yang digunakan adalah uji instrumen validitas dan reliabilitas, uji asumsi klasik, uji hipotesis, analisis korelasi, analisis jalur, dan sobel test. Alat bantu pengelolaan data menggunakan SPSS for windows. Hasil penelitian menunjukan bahwa kompetensi berpengaruh positif terhadap kepuasan kerja. Komunikasi organisasi berpengaruh positif terhadap kepuasan kerja. Kompetensi berpengaruh positif terhadap kinerja. Komunikasi organisasi tidak berpengaruh terhadap kinerja. Kepuasan kerja dapat memediasi antara kompetensi dan kinerja serta kepuasan kerja dapat memediasi antara komunikasi organisasi dan kinerja.
\end{abstract}

\section{Pendahuluan}

Pendamping PKH merupakan petugas lapangan yang berperan memberikan layanan pendampingan atau menfasilitasi peserta $\mathrm{PKH}$. Pendamping memiliki tugas untuk memberi informasi kepada KPM, melakukan pendampingan dan memberikan informasi, memberikan pemahaman dan tujuan $\mathrm{PKH}$, prosedur dan mekanisme $\mathrm{PKH}$, hak dan kewajiban penerima $\mathrm{PKH}$, syarat penerima PKH, dan manfaat PKH di wilayah tempat ia bertugas. Pendamping PKH juga mengunjungi fasilitas pendidikan dan fasilitas kesehatan untuk melakukan 
pengecekan terhadap pengisian formulir verifikasi kesehatan dan verifikasi pendidikan peserta $\mathrm{PKH}$.

Di Kabupaten Kebumen terdapat petugas pendamping PKH yang memiliki tugas masingmasing di setiap kecamatan. Jumlah pendamping PKH di setiap kecamatan berbeda-beda tergantung seberapa banyak jumlah KPM di setiap kecamatan. Berikut jumlah pendamping PKH di Kabupaten Kebumen yang tersebar di 26 kecamatan di Kabupaten Kebumen.

Kinerja pendamping PKH secara langsung berpengaruh terhadap keberhasilan program keluarga harapan dalam membangun kesejahteraan masyarakat miskin. Menurut Mangkunegara (dalam Saputra, dkk., 2016) Kinerja merupakan hasil kerja secara kualitas maupun kuantitas yang dicapai oleh seseorang dalam melaksanakan tugas yang diberikan kepadanya sesuai dengan standar/kriteria yang telah ditetapkan. Kinerja pendamping PKH perlu diperhatikan guna memberikan dampak positif dalam pencapain tujuan dari program keluarga harapan. Penilaian kinerja pendamping PKH dilakukan setiap satu tahun sekali oleh koordinator kabupaten dengan memperhatiakan perilaku dan sikap dari para pendamping.

Berdasarkan wawancara dengan koordinator kabupaten menyimpulkan bahwa pendamping PKH di Kabupaten Kebumen dari tahun 2018 hingga 2020 lanjut menjadi pendamping. Penilaian kinerja yang dilakukan setiap akhir tahun dengan tujuan menilai bagaimana kinerja pendamping setiap tahunnya. Selain itu berdasarkan wawancara dengan beberapa pendamping PKH tingkat putus sekolah pada anak-anak KPM untuk tahun 2020 mengalami pengurangan dan tingkat kesadaran kesehatan juga meningkat. Hal ini terjadi akibat keberhasilan para pendamping PKH dalam memberikan informasi dan memotivasi para KPM terkait pentingnya pendidikan dan kesehatan.

Faktor yang mempengaruhi kinerja diantaranya adalah kompetensi, komunikasi organisasi, dan kepuasan kerja. Menurut Rahadi, dkk (2016) kompetensi merupakan sebuah kombinasi antara ketrampilan (skill), atribut personal, dan pengetahuan (knowledge) yang tercermin melalui perilaku kinerja (job behavior) yang dapat diamati, diukur, dan dievaluasi. Dalam kompetensi terdapat pengetahuan, ketrampilan, kemampuan, dan bakat (Sudarmanto, 2018).

Kompetensi yang berbeda beda pada setiap pendamping akan menciptakan kontribusi kinerja yang berbeda juga pada organisasi. Berdasarkan hal tersebut maka organisasi memiliki kriteria kompetensi tertentu mengenai pendamping yang akan dikerjakan yang sesuai dengan kebutuhan organisasi. Penelitian yang dilakukan oleh Putri \& Ardiana (2019) bahwa kompetensi memiliki pengaruh yang signifikan terhadap kinerja yang berarti bahwa ketika kompetensi yang dimiliki oleh pegawai semakin baik maka akan semakin dapat meningkatkan kinerja.

Berdasarkan wawancara kompetensi pendamping PKH sudah cukup baik terlihat dari kualifikasi tingkat pendidikan pendamping PKH di Kabupaten Kebumen minimal pendidikannya D3.. Selain itu pendamping PKH di seluruh kecamatan di Kabupaten Kebumen mampu meyelesaikan tugas yang diberikan dengan baik dibuktikan dengan pencapain rencana kegiatan pada bulan Januari hingga Desember tahun 2020 tercapai 100\%.

Faktor yang mempengaruhi kinerja selanjutnya adalah komunikasi organisasi. Dalam organisasi terdapat berbagai sumber daya manusia, ada yang berperan sebagai pemimpin, dan sebagian besar lainnya berperan sebagai anggota/karyawan. Semua orang yang terlibat dalam organisasi tersebut akan melakukan komunikasi. Tidak ada organisasi tanpa komunikasi, karena komunikasi merupakan bagian integral dari organisasi. Sesuai dengan hasil penelitian Afianto dan Utami, (2017) menyimpulkan bahwa komunikasi organisasi 
berpengaruh signifikan positif terhadap kinerja karyawan, artinya semakin baik komunikasi organisasi maka kinerja karyawan juga akan tinggi.

Berdasarkan wawancara dengan beberapa pendamping PKH dan ketua koordiantor Kabupeten Kebumen, menyatakan bahwa komunikasi yang terjadi dalam organisasi pedamping PKH terjalin dengan baik. Komunikasi antar pendamping PKH terjalin dengan baik, sejalan dengan perkembangan teknologi peertukaran informasi antara pendamping yang satu dengan yang lainnya menjadi lebih intens. Komunikasi terjadi dari pemerintah dan ketua sebagai atasan dan pendamping di tingkat kecamatan sebagai bawahan. Komunikasi yang terjadi di pendamping PKH cukup baik, tidak terjadi bias informasi karena dalam setiap kabupaten dan kecamatan terdapat koordinator masing masing.

Adanya peran dari faktor kompetensi dan komunikasi organisasi berkemungkinan belum cukup untuk meningkatkan kinerja sehingga diperlukan adanya mediasi kepuasan kerja bagi para pendamping. Hal ini sejalan dengan penelitian sebelumnya yang dilakukan oleh Prsyanto (2017) bahwa kepuasan dapat memediasi hubungan kompetensi karyawan terhadapan kinerja dan Ardiansyah (2016) diketahui bahwa peran kepuasan kerja memediasi komunikasi dan kinerja karyawan berpengaruh positif.

Menurut Rokib dan Santoso (2018) karyawan yang tingkat kepuasan kerjanya tinggi akan memiliki sikap positif terhadap pekerjaanya, sehingga dapat menunjukkan kinerja yang maksimal guna memenuhi tanggung jawab yang diterima dalam pekerjaanya.

Berdasarkan wawancara dengan pendamping PKH di Kabupaten Kebumen, mereka merasa puas bekerja sebagai pendamping PKH karena merasa cocok bekerja langsung di lapangan dan berinteraksi secara langsung bersama masyarakat. Selain itu, para pendamping PKH menyukai tantangan sehingga ketika berinteraksi dan menghadapi masyarakat dengan ekonomi yang rendah merasa tertantang sehingga puas bekerja sebagai pendamping PKH. Pendaping PKH juga merasa puas akan gaji yang mereka terima sesuai beban kerja.

\section{Kajian Teori dan Telaah Literatur}

\section{Kompetensi}

Kompetensi adalah karateristik dasar dari seseorang yang memungkinkannya memberikan kinerja unggul dalam pekerjaan, peran atau situasi tertentu (Marshall dalam Sudarmanto, 2018). Menurut Taufiqirohman, 2009 (dalam Putri dan Ardiana, 2019) menyebutkan bahwa kompetensi setiap orang dapat diukur dengan jelas dan dapat ditujukkan untuk membedakakn perilaku unggul atau rata-rata seseorang. Kompetensi dapat berupa penguasaan masalah, ketrampilan kognitif maupun ketrampilan perilaku, tujuan, perangai, konsep diri, sikap atau nilai.

\section{Komunikasi Organisasi}

Redding dan Sanborn (dalam Muhammad, 2019) mengatakan bahwa komunikasi organisasi adalah pengiriman dan penerimaan informasi dalam organisasi yang kompleks. Sedangkan menurut Thayer (dalam Muhammad, 2019) mengatakan bahwa komunikasi sebagai arus data yang akan melayani komunikasi organisasi dan proses interkomunikasi dalam beberapa cara. Dalam komunikasi organisasi terdapat tiga sistem yaitu: a. Berkenaan dengan kerja organisasi seperti data mengenai tugas-tugas atau beroperasinya organisasi; $b$. Berkenaan dengan pengaturan organisasi seperti perintah-perintah, aturan-aturan, dan petunjuk-petujuk; c. Berkenaan dengan pemeliharaan dan pengembangan organisasi. 
Menurut Goldhaber, 1986 (dalam Muhammad, 2019) menyatakan bahwa komunikasi organisasi sebagai berikut, "communication is the process of creating and exchanging messages within a network of interpendent relationship to cope with environtmental uncertainity". Atau dengan kata lain komunikasi organisasi adalah proses menciptakan dan saling menukar pesan dalam satu jaringan hubungan yang saling tergantung satu sama lain untuk mengatasi lingkungan yang tidak pasti atau yang selalu berubah ubah. Pengertian ini megandung tujuh konsep kunci yaitu proses, pesan, jaringan, saling tergantung, hubungan, lingkungan, dan ketidakpastian.

\section{Kepuasan Kerja}

Robbins dan Judge (2008) menyatakan bahwa kepuasan kerja adalah suatu perasaan positif tentang pekerjaan seseorang yang merupakan hasil evaluasi karateristknya. Menurut Rokib dan Santoso (2019) karyawan yang tingkat kepuasan kerjanya tinggi akan memiliki sikap positif terhadap pekerjaanya, sehingga dapat menunjukkan kinerja yang maksimal guna memenuhi tanggung jawab yang diterima dalam pekerjaanya. Selanjutnya Davis dan Newstrom (dalam Sinembela dan Sinambela, 2019) menyatakan bahwa kepuasan kerja adalah seperangkat perasaan pegawai tentang menyenangkan atau tidaknya pekerjaan mereka.

Menurut Fattah, (2017) menyatakan bahwa kepuasan kerja adalah gambaran perasaan senang dan tidak seseorang karyawan terhadap pekerjaan yang dilakukan, kepuasan kerja merupakan respons emosional pegawai terhadap situasi kerja yang ditentukan oleh pencapaian hasil, memenuhi atau melampaui harapan.

Davis dan Newstrom (dalam Sinambela, 2019) menyatakan bahwa kepuasan kerja adalah seperangkat perasaan pegawai tentang menyenangkan atau tidaknya pekerjaan mereka.

\section{Kinerja}

Menurut Amstrong dan Baron (dalam Wibowo, 2010) Kinerja merupakan hasil pekerjaan yang mempunyai hubungan kuat dengan tujuan strategis organisasi, kepuasan, dan memberikan kontribusi ekonomi. Bernadin, 2001 (dalam Sudarmanto 2018) menyatakan kinerja merupakan catatan hasil yang diproduksi (dihasilkan) atas fungsi pekerjaan tertentu atau aktivitas-aktivitas selama periode waktu tertentu.

Menurut Murphy, 1998 (dalam Sudarmanto, 2018) menyatakan kinerja merupakan seperangkat perilaku yang relevan dengan tujuan organisasi atau unit organisasi tempat orang bekerja. Kinerja adalah merupakan implementasi dari rencana yang telah disusun. Implementasi kinerja dilakukan oleh sumber daya mnausia yang memiliki kemampuan, kompetensi, motivasi, dan kepentingan (Wibowo, 2010).

Kinerja didefinisikan sebagai kemampuan individu dalam melakukan sesuatu dengan keahlian tertentu. Senada dengan pendapat Stephen Robbins, 1996 (dalam Sinambela dan Sinambela 2019) mengemukakan bahwa kinerja diartikan sebagai hasil evaluasi terhadap pekerjaan yang dilakukan individu dibandingkan dengan kriteria yang telah ditetapkan bersama. Dari kedua pengertian tersebut menunjukkan bahwa kinerja seseorang sangatlah perlu, sebab dengan kinerja akan diketahui seberapa jauh kemampuan seseorang dalam melaksanakan tugasnya. Untuk mengetahui hal itu diperlukan penentuan kriteria pencapaian yang ditetapkan secara bersama-sama. 
Menurut Mangkuprawira, 2009 (dalam Putri dan Ardiana, 2019) kinerja adalah hasil kerja yang dapat dicapai oleh seseorang atau kelompok orang dalam satu organisasi sesuai dengan wewenang dan tanggungjawab masing-masing dalam upaya pencapaian tujuan organisasi. Sedangkan menurut Mangkunegara (dalam Saputra, dkk., 2016) Kinerja merupakan hasil kerja secara kualitas maupun kuantitas yang dicapai oleh seseorang dalam melaksanakan tugas yang diberikan kepadanya sesuai dengan standar/kriteria yang telah ditetapkan.

\section{Kerangka Pemikiran}

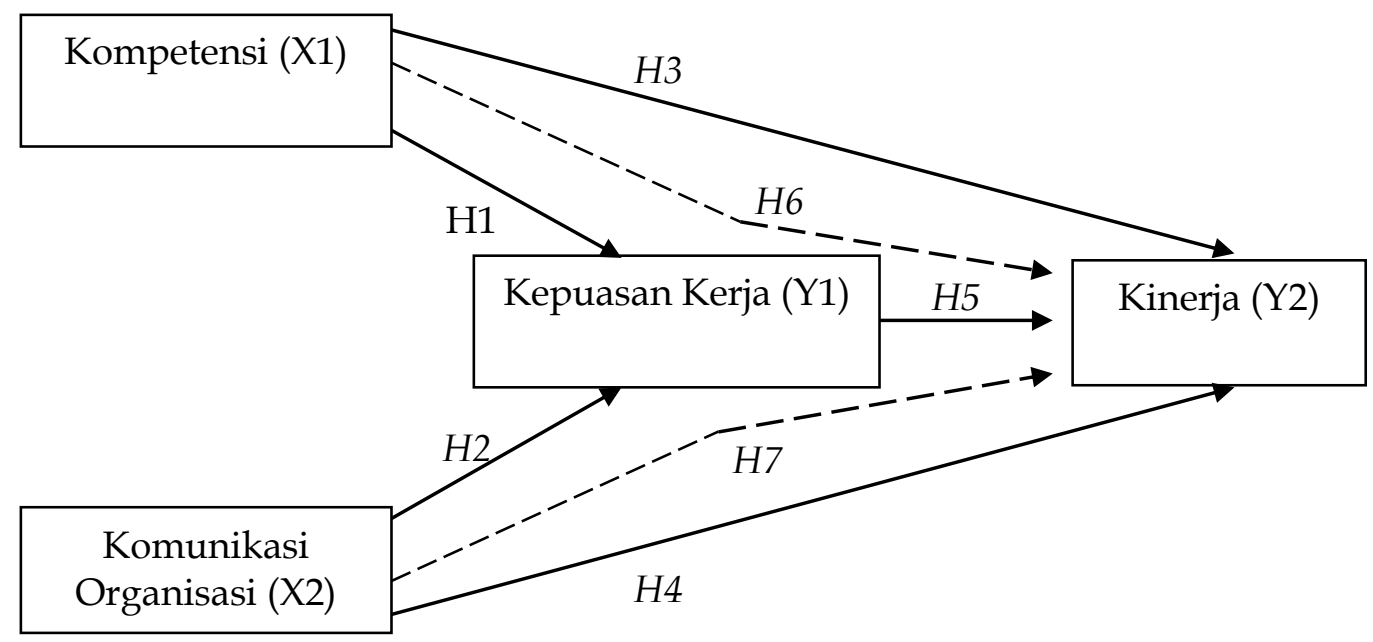

\section{Metode Penelitian}

\section{Data dan Teknik Pengambilan Data}

Data primer diperoleh dari penyebaran kuisioner dan wawancara langsung dengan pendamping PKH dan koordinator Kabupaten Kebumen.

\section{Populasi dan Sampel}

Populasi adalah wilayah generalisasi yang terdiri atas obyek dan subyek yang mempunyai kualitas dan karateristik tertentu yang ditetapkan oleh peneliti untuk dipelajari dan kemudian ditarik kesimpulannya (Sugiyono, 2010). Populasi dalam penelitian ini adalah pendamping PKH di Kabupaten Kebumen yang berjumlah 247.

Sampel adalah bagian dari jumlah dan karateristik yang dimiliki oleh populasi (Sugiyono, 2010). Bila populasi besar, dan peneliti tidak mungkin mempelajari semua yang ada pada populasi, misalya karena keterbatasan dana, tenaga, dan waktu, maka peneliti dapat menggunakan sampel yang diambil dari populasi itu sehingga sampel yang diambil dari populasi harus benar-benar representatif/mewakili (Sugiyono, 2010). Sampel dalam penelitian ini yaitu berjumlah 72 pendamping $\mathrm{PKH}$.

\section{Teknik Pengambilan Sampel}

Pada penelitian ini teknik sampling yang digunakan yaitu Probability sampling. Probability samping adalah teknik pengambilan sampel yang memberikan peluang yang sama bagi setiap unsur (anggota) populasi untuk dipilih menjadi anggota sampel. Teknik ini meliputi 
simple random sampling, proportionate stratified random sampling, disproportionate stratified random sampling, cluster sampling (Sugiyono, 2010).

Dari berbagai macam teknik probability sampling, penulis menggunakan teknik simple random sampling. Dikatakan simple (sederhana) karena pengambilan anggota sampel dari populasi dilakukan secara acak tanpa memperhatikan strata yang ada dalam populasi (Sugiyono, 2010). Cara demikian dilakukan apabila anggota populasi dianggap homogen.

Jumlah populasi dalam penelitian ini adalah seluruh pendamping PKH Kabupaten Kebumen yang berjumlah 247 orang. Dalam penelitian ini penulis mempersempit populasi yaitu dengan cara menghitung ukuran sampel yang dilakukan dengan menggunakan rumus Slovin.

\section{Alat Analisis Data}

Perhitungan pengolahan data dalam penelitian ini menggunakan alat bantu yang berupa program aplikasi komputer yaitu IBM SPSS Statistic for Windows versi 25.

\section{Hasil dan Pembahasan}

\section{Uji Validitas}

Uji validitas digunakan untuk mengukur sah atau valid tidaknya suatu kuesioner.

Df $=72-2=70$, diperoleh rtabel $=0,2319$

Tabel 1. Hasil Uji Validitas Kompetensi

\begin{tabular}{lllll}
\hline Variabel & Butir & $\mathbf{r}_{\text {hitung }}$ & $\mathbf{r}_{\text {tabel }}$ & Keterangan \\
\hline & 1 & 0,656 & 0,2319 & Valid \\
& 2 & 0,765 & 0,2319 & Valid \\
Kompetensi & 3 & 0,794 & 0,2319 & Valid \\
& 4 & 0,770 & 0,2319 & Valid \\
& 5 & 0,737 & 0,2319 & Valid \\
& 6 & 0,755 & 0,2319 & Valid \\
& 7 & 0,749 & 0,2319 & Valid \\
\hline
\end{tabular}

Sumber: Data primer yang diolah, 2021

Tabel 2. Hasil Uji Validitas Komunikasi Organisasi

\begin{tabular}{lllll}
\hline Variabel & Butir & $\mathbf{r}_{\text {hitung }}$ & $\mathbf{r}_{\text {tabel }}$ & Keterangan \\
\hline & 1 & 0,604 & 0,2319 & Valid \\
& 2 & 0,671 & 0,2319 & Valid \\
Komunikasi & 3 & 0,694 & 0,2319 & Valid \\
Organisasi & 5 & 0,636 & 0,2319 & Valid \\
& 6 & 0,725 & 0,2319 & Valid \\
& 7 & 0,808 & 0,2319 & Valid \\
& 8 & 0,705 & 0,2319 & Valid \\
\hline
\end{tabular}

Sumber: Data primer yang diolah, 2021 
Tabel 3. Hasil Uji Validitas Kepuasan Kerja

\begin{tabular}{lllll}
\hline Variabel & Butir & $\mathbf{r}_{\text {hitung }}$ & $\mathbf{r}_{\text {tabel }}$ & Keterangan \\
\hline & 1 & 0,570 & 0,2319 & Valid \\
& 2 & 0,741 & 0,2319 & Valid \\
& 3 & 0,563 & 0,2319 & Valid \\
Kepuasan & 4 & 0,681 & 0,2319 & Valid \\
Kerja & 5 & 0,657 & 0,2319 & Valid \\
& 7 & 0,664 & 0,2319 & Valid \\
& 8 & 0,599 & 0,2319 & Valid \\
& 9 & 0,473 & 0,2319 & Valid \\
& 0,607 & 0,2319 & Valid \\
\multicolumn{5}{l}{ Sumber: Data primer yang diolah, 2021 } \\
\multicolumn{5}{l}{}
\end{tabular}

Tabel 4 Hasil Uji Validitas Kinerja

\begin{tabular}{lllll}
\hline Variabel & Butir & $\mathbf{r}_{\text {hitung }}$ & $\mathbf{r}_{\text {tabel }}$ & Keterangan \\
\hline \multirow{6}{*}{ Kinerja } & 1 & 0,845 & 0,2319 & Valid \\
& 2 & 0,828 & 0,2319 & Valid \\
& 3 & 0,806 & 0,2319 & Valid \\
& 4 & 0,812 & 0,2319 & Valid \\
& 5 & 0,686 & 0,2319 & Valid \\
& 6 & 0,738 & 0,2319 & Valid \\
\hline \multicolumn{5}{c}{ Sumber: Data primer yang diolah, 2021} \\
\end{tabular}

Berdasarkan hasil uji validitas, dapat dijelaskan bahwa rhitung > rtabel $(0,2319)$, dengan nilai signifikasi 0,000 $<0,05$ sehingga semua item pernyataan yang dipakai pada variabel diatas dinyatakan valid (sah).

\section{Uji Reliabilitas}

Uji reliabilitas dilakukan dengan membandingkan nilai cronbach's alpha dengan nilai $r$ tabel. Dinyatakan reliabel apabila nilai cronbach's alpha $>0,60$.

Tabel 5. Hasil Uji Realibilitas

\begin{tabular}{|c|c|c|c|c|}
\hline \multirow[b]{2}{*}{ No } & \multirow[b]{2}{*}{ Variabel } & \multicolumn{2}{|l|}{ Cronbach's } & \multirow[b]{2}{*}{ Ket. } \\
\hline & & Alpha & $\mathbf{r}_{\text {kritis }}$ & \\
\hline 1 & Kompetensi & 0,867 & 0,60 & Reliabel \\
\hline 2 & $\begin{array}{l}\text { Komunikasi } \\
\text { Organisasi }\end{array}$ & 0,844 & 0,60 & Reliabel \\
\hline 3 & $\begin{array}{l}\text { Kepuasan } \\
\text { Kerja }\end{array}$ & 0,822 & 0,60 & Reliabel \\
\hline 4 & Kinerja & 0,877 & 0,60 & Reliabel \\
\hline
\end{tabular}

Berdasarkan Tabel diatas dapat dilihat bahwa cronbach's alpha pada variabel kompetensi sebesar 0,867 untuk variabel komunikasi organisasi sebesar 0,844 untuk variabel kepuasan kerja sebesar 0,822 dan untuk variabel kinerja sebesar 0,877. Hasil uji reliabilitas tersebut menunjukan bahwa semua variabel mempunyai nilai Cronbach's Alpha yang cukup besar yaitu $>0,60$ sehingga dapat dikatakan semua konsep pengukur masing-masing variabel dari kuisioner adalah reliabel. 


\section{Uji Asumsi Klasik}

\section{Uji Multikolinieritas}

Uji multikolinieritas bertujuan untuk menguji apakah model regresi ditemukan adanya korelasi antar variabel bebas (independen).

Tabel 6. Uji Multikolinieritas Struktural I

\begin{tabular}{ccc}
\hline Variabel Bebas & \multicolumn{2}{c}{ Collinierity Statistics } \\
\cline { 2 - 3 } & Tolerance & VIF \\
\hline Kompetensi $\left(\mathrm{X}_{1}\right)$ & 0,696 & 1,438 \\
Komunikasi & 0,696 & 1,438 \\
Organisasi $\left(\mathrm{X}_{2}\right)$ & & \\
\hline Sumber: Data primer yang diolah, 2021 &
\end{tabular}

Berdasarkan uji multikolinieritas struktur I di atas, seluruh nilai tolerance $\geq 0,10$ dan VIF $\leq 10$ maka dapat disimpulkan tidak terjadi multikolonieritas antara variabel bebas.

Tabel 7. Uji Multikolinieritas Struktural II

\begin{tabular}{lll}
\hline Variabel Bebas & \multicolumn{2}{l}{$\begin{array}{l}\text { Collinierity } \\
\text { Statistics }\end{array}$} \\
\cline { 2 - 3 } & Tolerance & VIF \\
\hline Kompetensi $\left(\mathrm{X}_{1}\right)$ & 0,555 & 1,802 \\
Komunikasi & 0,606 & 1,651 \\
Organisasi $\left(\mathrm{X}_{2}\right)$ & & \\
Kepuasan Kerja $\left(\mathrm{Y}_{1}\right)$ & 0,531 & 1,885 \\
\hline Sumber: Data primer yang diolah, 2021 &
\end{tabular}

Berdasarkan tabel di atas, seluruh nilai tolerance $\geq 0,10$ dan VIF $\leq 10$ Maka dapat disimpulkan tidak terjadi multikolonieritas antara variabel bebas.

\section{Uji Heteroskedastisitas}

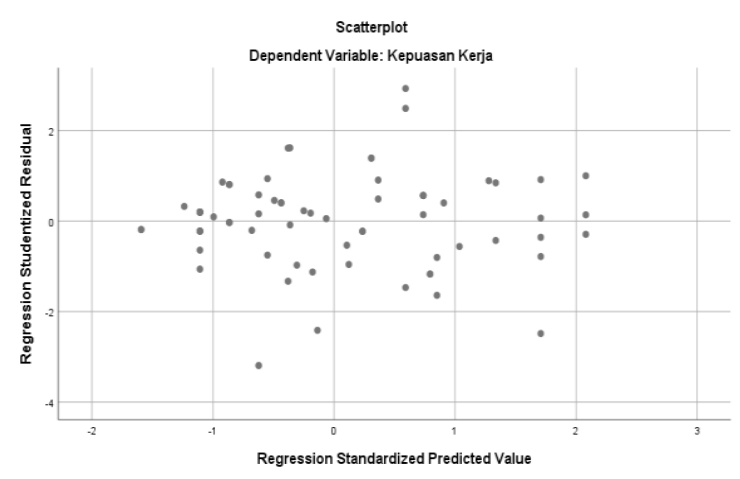

Gambar 1. Uji Heteroskedastisitas Struktural I

Sumber: Data primer yang diolah, 2021 


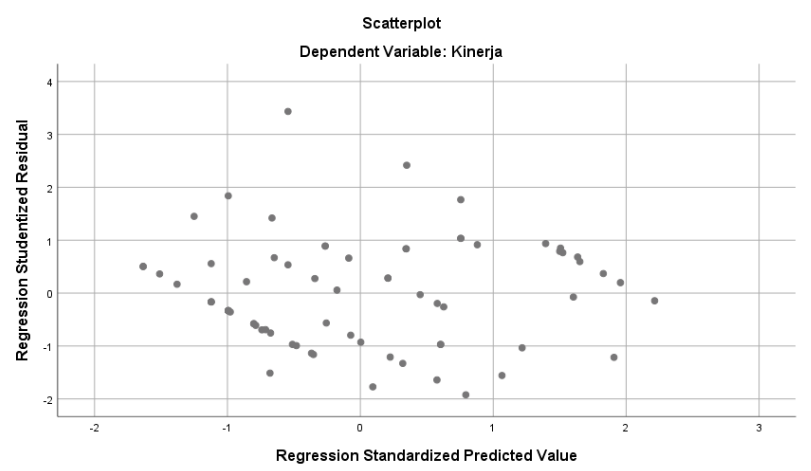

Gambar 2. Uji Heteroskedastisitas Struktural II

Sumber: Data primer yang diolah, 2021

Berdasarkan gambar di atas dari hasil output SPSS dapat diketahui bahwa tidak terdapat pola yang jelas, serta titik-titik pada grafik menyebar di atas dan di bawah angka 0 (nol) pada sumbu Y, maka tidak terjadi heteroskedastisitas sehingga model regresi tersebut dapat dipakai.

\section{Uji Normalitas}

Pengujian ini bertujuan untuk menguji apakah dalam model regresi variabel pengganggu atau residual memiliki distribusi.

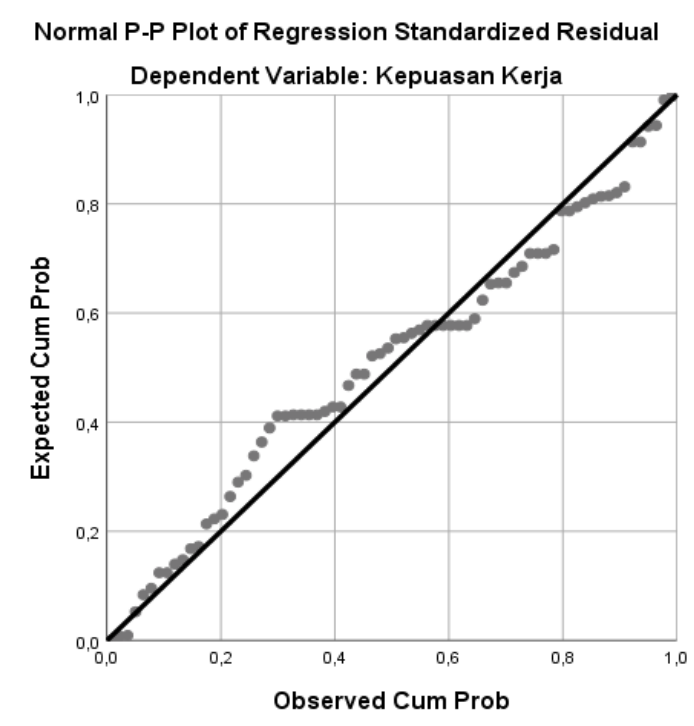

Gambar 3. Uji Normalitas Struktural I

Sumber: Data primer yang diolah, 2021 


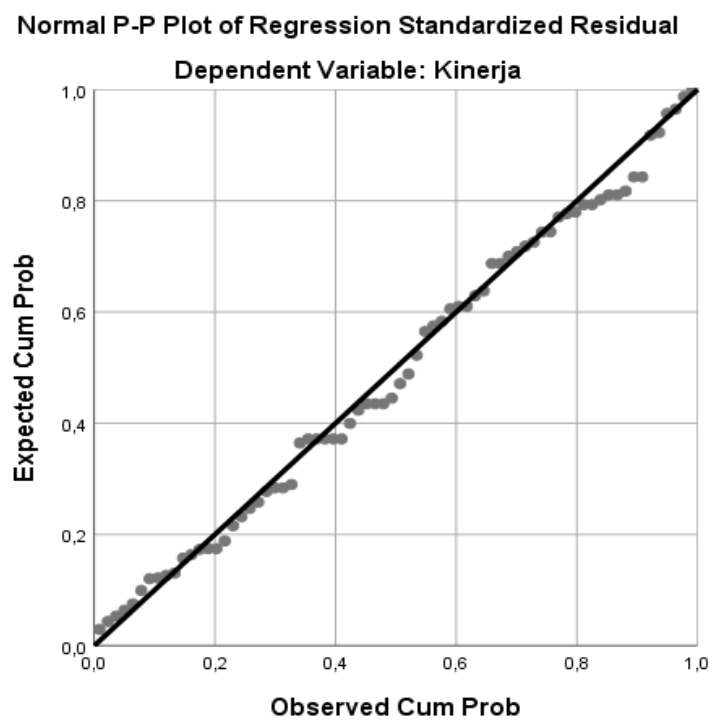

\section{Gambar 4. Uji Normalitas Struktural II}

Sumber: Data primer yang diolah, 2021

Berdasarkan gambar di atas dari hasil output SPSS dapat diketahui bahwa data menyebar di sekitar garis diagonal dan mengikuti arah garis diagonal, maka model regresi tersebut memenuhi asumsi normalitas.

\section{Uji Hipotesis}

\section{Uji Parsial (uji t)}

Uji t untuk mengetahui pengaruh secara parsial atau sendiri-sendiri variabel bebas terhadap variabel terikat. Dalam pengujian ini ditentukan tingkat signfikan sebesar $5 \%(\alpha=0,05)$ dengan tingkat keyakinan sebesar 95\% $(0,95)$.

Penentuan ttabel untuk persamaan 1 dengan menggunakan rumus $\mathrm{df}=\mathrm{n}-\mathrm{k}(72-2=70)$ diperoleh angka pada ttabel sebesar 1,994.

Tabel 8. Hasil Uji Parsial (Uji t) Struktural I

\begin{tabular}{|c|c|c|c|c|c|c|}
\hline & \multirow{2}{*}{ Model } & \multicolumn{2}{|c|}{$\begin{array}{c}\text { Unstandardized } \\
\text { Coefficients }\end{array}$} & \multirow{2}{*}{$\begin{array}{c}\text { Standardized } \\
\text { Coefficients } \\
\text { Beta }\end{array}$} & \multirow{2}{*}{$\mathrm{T}$} & \multirow{2}{*}{ Sig. } \\
\hline & & B & $\begin{array}{l}\text { Std. } \\
\text { Error }\end{array}$ & & & \\
\hline \multirow[t]{3}{*}{1} & (Constant) & 8,077 & 3,123 & & 2,586 & 012 \\
\hline & Kompetensi &, 544 & ,130 & ,440 & 4,183 & ,000 \\
\hline & $\begin{array}{c}\text { Komunikasi } \\
\text { Organisasi }\end{array}$ & ,417 & 131 & ,336 & 3,197 & ,002 \\
\hline
\end{tabular}

a. Dependent Variable: Kepuasan Kerja

Sumber: Data primer yang diolah, 2021

Berdasarkan hasil uji t diatas, maka dapat disimpulkan sebagai berikut:

a. Kompetensi (X1) Terhadap Kepuasan Kerja (Y1)

Berdasarkan pada tabel dapat dilihat bahwa nilai thitung sebesar 4,183 $>$ ttabel 1,994. Dilihat dari signifikan, kompetensi memiliki nilai sebesar $0,000<0,05$. Maka dapat disimpulkan 
bahwa Kompetensi X1 terbukti mempunyai pengaruh positif dan signifikan terhadap kepuasan kerja Y1 sehingga dapat disimpulkan H1 diterima.

\section{b. Komunikasi Organisasi (X2) Terhadap Kepuasan Kerja (Y1)}

Berdasarkan pada tabel dapat dilihat bahwa nilai thitung sebesar 3,197 > ttabel 1,994. Dilihat dari signifikan, komunikasi organisasi memiliki nilai sebesar 0,002 < 0,05. Maka dapat disimpulkan bahwa komunikasi organisasi X1 terbukti mempunyai pengaruh positif dan signifikan terhadap kepuasan kerja Y1 sehingga dapat disimpulkan H2 diterima.

Penentuan ttabel untuk persamaan 2 dengan menggunakan rumus $\mathrm{df}=\mathrm{n}-\mathrm{k}(72-3=69)$ diperoleh angka pada ttabel sebesar 1,995.

Tabel 9. Hasil Uji Parsial (Uji t) Struktural II

\begin{tabular}{|c|c|c|c|c|c|c|}
\hline & \multirow{2}{*}{ Model } & \multicolumn{2}{|c|}{$\begin{array}{l}\text { Unstandardized } \\
\text { Coefficients }\end{array}$} & \multirow{2}{*}{$\begin{array}{c}\begin{array}{c}\text { Standardized } \\
\text { Coefficients }\end{array} \\
\text { Beta }\end{array}$} & \multirow{2}{*}{$\mathbf{T}$} & \multirow{2}{*}{ Sig. } \\
\hline & & B & $\begin{array}{l}\text { Std. } \\
\text { Error }\end{array}$ & & & \\
\hline \multirow[t]{4}{*}{1} & (Constant) & ,568 & 1,899 & & ,299 & ,766 \\
\hline & Kompetensi & 343 & 085 & 402 & 4,052 & 000 \\
\hline & $\begin{array}{l}\text { Komunikasi } \\
\text { Organisasi }\end{array}$ & 158 & ,081 & 185 & 1,947 & ,056 \\
\hline & Kepuasan Kerja & 230 & 070 & 334 & 3,289 & 002 \\
\hline
\end{tabular}

Berdasarkan hasil uji t diatas, maka dapat disimpulkan sebagai berikut:

a. Kompetensi (X1) Terhadap Kinerja (Y2)

Berdasarkan pada tabel dapat dilihat bahwa nilai thitung sebesar 4,052 >ttabel 1,995. Dilihat dari signifikan, kompetensi memiliki nilai sebesar 0,000 $<0,05$. Maka dapat disimpulkan bahwa Kompetensi X1 terbukti mempunyai pengaruh positif dan signifikan terhadap kinerja Y2 sehingga dapat disimpulkan $\mathrm{H} 3$ diterima.

b. Komunikasi Organisasi (X2) Terhadap Kinerja (Y2)

Berdasarkan pada tabel dapat dilihat bahwa nilai thitung sebesar 1,947 < ttabel 1,995. Dilihat dari signifikan, komunikasi organisasi memiliki nilai sebesar 0,056 > 0,05. Maka dapat disimpulkan bahwa komunikasi organisasi X1 tidak berpengaruh terhadap kinerja Y2 sehingga dapat disimpulkan $\mathrm{H} 4$ ditolak.

c. Kepuasan Kerja (Y1) terhadap Kinerja (Y2)

Berdasarkan pada tabel dapat dilihat bahwa nilai $t_{\text {hitung }}$ sebesar 3,289 $>t_{\text {tabel }} 1,995$. Dilihat dari signifikan, Komitmen Organisasi memiliki nilai sebesar 0,002 $<0,05$. Maka dapat disimpulkan bahwa kepuasan kerja $Y_{1}$ terbukti mempunyai pengaruh positif dan signifikan terhadap kinerja $\mathrm{Y}_{2}$ dapat disimpulkan $\mathrm{H}_{5}$ diterima.

\section{Koefisien Determinasi (R2)}

Koefisien determinasi digunakan untuk melihat seberapa besar pengaruh variabel independen terhadap dependen. 
Tabel 10. Hasil Output Koefisien Determinasi Struktural I

Model Summaryb

\begin{tabular}{lllll}
\hline Model & $\mathrm{R}$ & $\mathrm{R}$ Square & $\begin{array}{l}\text { Adjusted R } \\
\text { Square }\end{array}$ & $\begin{array}{l}\text { Std. Error of } \\
\text { the Estimate }\end{array}$ \\
\hline 1 &, $685^{\mathrm{a}}$ &, 469 &, 454 & 2,419 \\
\hline
\end{tabular}

a. Predictors: (Constant), Komunikasi Organisasi, Kompetensi

b. Dependent Variable: Kepuasan Kerja

Sumber: Data primer yang diolah, 2021

Berdasarkan output diatas, dapat dilihat nilai Adjusted R Square 0,454 atau dapat diartikan 45,4\% kepuasan kerja pada Pendamping PKH di Kabupaten Kebumen dipengaruhi oleh Kompetensi (X1) dan Kepuasan Kerja (X2), sedangkan sisanya 54,6\% dipengaruhi oleh variabel lain yang tidak ada dalam penelitian ini.

Tabel 11. Hasil Output Koefisien Determinasi Struktural II

Model Summary ${ }^{\mathrm{b}}$

\begin{tabular}{lllll}
\hline Model & $R$ & R Square & Adjusted R Square & Std. Error of the Estimate \\
\hline 1 &, $793^{\mathrm{a}}$ &, 628 &, 612 & 1,404 \\
\hline $\begin{array}{l}\text { a. Predictors: (Constant), Kepuasan Kerja, Komunikasi Organisasi, Kompetensi } \\
\text { b. Dependent Variable: Kinerja }\end{array}$
\end{tabular}

Berdasarkan output di atas dapat dilihat nilai Adjusted R Square 0,612 atau dapat diartikan sebesar 61,2\% kinerja pada pendamping PKH di Kabupaten Kebumen dipengaruhi oleh Kompetensi (X1), Komunikasi Organisasi (X2) dan Kepuasan Kerja (Y1), sedangkan sisanya $38,8 \%$ dipengaruhi oleh variabel lain yang tidak ada dalam penelitian ini.

\section{Analisis Korelasi}

Tabel 12. Analisis Korelasi

Correlations




Berdasarkan tabel output SPSS tersebut, nilai korelasi antara Kompetensi terhadap Komunikasi Organisasi sebesar 0,552 dengan tingkat signifikan 0,000 yang artinya terdapat hubungan atau korelasi yang kuat dan signifikan antara Kompetensi terhadap Komunikasi Organisasi.

\section{Analisis Jalur}

\section{Koefisien Jalur}

Koefisien jalur menunjukkan kuatnya pengaruh variabel independen terhadap dependen. Koefisien jalur dapat dihitung dengan persamaan struktural yang terdiri dari dua persamaan dimana X1 dan X2 adalah variabel independen, independen $\mathrm{Y} 1$ dan $\mathrm{Y} 2$ adalah variabel dependen yang dirumuskan sebagai berikut:

a. $\mathrm{Y} 1=\mathrm{PY} 1 \mathrm{X} 1+\mathrm{PY} 1 \mathrm{X} 2+£ 1$ (sebagai persamaan struktural 1)

b. $Y 2=P Y 2 X 1+P Y 2 X 2+Y 1+£ 2$ (sebagai persamaan struktural 2$)$

Keterangan:

Y1 : Variabel Kepuasan Kerja

Y2 : Variabel Kinerja

$\mathrm{X} 1$ : Variabel Kompetensi

X2 : Variabel Komunikasi Organisasi

$£ 1 £ 2$ : Nilai Residual (Error)

Berikut hasil koefisien jalur struktural I dan II sebagai berikut:

Tabel 13. Hasil Uji Parsial (Uji t) Struktural I

\begin{tabular}{|c|c|c|c|c|c|c|}
\hline & \multirow{2}{*}{ Model } & \multicolumn{2}{|c|}{$\begin{array}{l}\text { Unstandardized } \\
\text { Coefficients }\end{array}$} & \multirow{2}{*}{$\begin{array}{c}\text { Standardized } \\
\text { Coefficients } \\
\text { Beta }\end{array}$} & \multirow{2}{*}{$\mathrm{T}$} & \multirow{2}{*}{ Sig. } \\
\hline & & B & $\begin{array}{l}\text { Std. } \\
\text { Error }\end{array}$ & & & \\
\hline \multirow[t]{3}{*}{1} & (Constant) & 8,077 & 3,123 & & 2,586 & ,012 \\
\hline & Kompetensi & ,544 & 130 & ,440 & 4,183 & ,000 \\
\hline & Komunikasi & ,417 & 131 & ,336 & 3,197 & ,002 \\
\hline
\end{tabular}

a. Dependent Variable: Kepuasan Kerja

Sumber: Data primer yang diolah, 2021

Berdasarkan tabel IV-17 output SPSS tersebut menunjukkan hasil output coefficients pada kolom standardized coefficients beta maka dapat dibuat persamaan regresi sebagai berikut:

$$
\begin{aligned}
& € 1=\sqrt{1-R^{2}}=\sqrt{1-0,469}=\sqrt{0,531}=0,729 \\
& Y 1=0,440 X 1+0,336 X 2+0,729
\end{aligned}
$$

Nilai-nilai P1 P2 dan € dapat dijelaskan sebagai berikut:

a. Koefisien regresi variabel Kompetensi $(X 1)=0,440$

Koefisien regresi untuk X1 sebesar 0,440 menunjukkan bahwa dengan adanya Kompetensi meningkatkan Kepuasan Kerja sebesar 0,440. Hal ini menunjukkan semakin tinggi nilai koefisien regresi X1 berarti kepuasan kerja akan meningkat.

b. Koefisien regresi variabel Komunikasi Organisasi $(X 2)=0,336$

Koefisien regresi untuk X2 sebesar 0,336 menunjukkan bahwa dengan adanya komunikasi organisasi meningkatkan kepuasan kerja 0,336. Hal ini menunjukkan semakin tinggi nilai koefisien regresi X2 berarti kepuasan kerja akan meningkat.

c. Nilai Residu

Nilai residu sebesar 0,729 menunjukkan bahwa kepuasan kerja pada pendamping PKH di Kabupaten Kebumen dapat dijelaskan oleh variabel Kompetensi (X1) dan Komunikasi Organisasi(X2) sebesar 0,729 atau 72,9\%. 
Tabel 14. Hasil Uji Parsial (Uji t) Struktural II

\begin{tabular}{|c|c|c|c|c|c|c|}
\hline & \multirow{2}{*}{ Model } & \multicolumn{2}{|c|}{$\begin{array}{l}\text { Unstandardized } \\
\text { Coefficients }\end{array}$} & $\begin{array}{l}\text { Standardized } \\
\text { Coefficients }\end{array}$ & \multirow{2}{*}{$\mathrm{T}$} & \multirow{2}{*}{ Sig. } \\
\hline & & B & $\begin{array}{l}\text { Std. } \\
\text { Error }\end{array}$ & Beta & & \\
\hline \multirow[t]{5}{*}{1} & (Constant) & ,568 & 1,899 & & ,299 & 766 \\
\hline & Kompetensi & 343 & 085 & 402 & 4,052 & 000 \\
\hline & Komunikasi & 158 & 081 & 185 & 1,947 & ,056 \\
\hline & Organisasi & & & & & \\
\hline & Kepuasan Kerja & 230 & , 070 & ,334 & 3,289 & ,002 \\
\hline
\end{tabular}

a. Dependent Variable: Kinerja

Sumber: Data primer yang diolah, 2021

Berdasarkan tabel IV-18 output SPSS tersebut menunjukkan hasil output coefficients pada kolom standardized coefficients beta maka dapat dibuat persamaan regresi sebagai berikut:

$$
\begin{aligned}
& € 2=\sqrt{1-R^{2}}=\sqrt{1-0,628}=\sqrt{0,372}=0,609 \\
& Y 2=0,402 X 1+0,185 X 2+0,334 Y 1+0,609
\end{aligned}
$$

Nilai-nilai P1 P2 dan $€$ dapat dijelaskan sebagai berikut:

a. Koefisien regresi variabel Kompetensi $(X 1)=0,402$

Koefisien regresi untuk X1 sebesar 0,0402 menunjukkan bahwa dengan adanya Kompetensi meningkatkan kinerja sebasar 0,402. Hal ini menunjukkan semakin tinggi nilai koefisien regresi $\mathrm{X} 1$ berarti kinerja akan meningkat.

b. Koefisien regresi variabel Komunikasi Organisasi $(X 2)=0,185$

Koefisien regresi untuk X2 sebesar 0,185 menunjukkan bahwa dengan adanya komunikasi organisasi meningkatkan kinerja 0,185. Hal ini menunjukkan semakin tinggi nilai koefisien regresi $\mathrm{X} 2$ berarti kinerja akan meningkat.

c. Koefisien regresi variabel Kepuasan Kerja $(\mathrm{Y} 1)=0,334$

Koefisien regresi untuk Y1 sebesar 0,334 menunjukan bahwa dengan adanya kepuasan kerja akan meningkatkan kinerja sebesar 0,334. Hal ini menunjukkan semakin tinggi nilai koefisien regresi $Y 1$ berarti kinerja akan meningkat.

d. Nilai Residu

Nilai residu sebesar 0,609 menunjukkan bahwa kinerja pada pendamping $\mathrm{PKH}$ di Kabupaten Kebumen dapat dijelaskan oleh variabel Kompetensi (X1), Komunikasi Organisasi(X2), dan Kepuasan Kerja (Y1) sebesar 0,609 atau 60,9\%.

\section{Pengaruh langsung (Direct Effect atau DE)}

Untuk menghitung pengaruh langsung, digunakan fomula sebagai berikut :

a. Pengaruh variabel kompetensi terhadap kepuasan kerja.

$\mathrm{X}_{1} \rightarrow \mathrm{Y}_{1}=0,440$

b. Pengaruh komunikasi organisasi terhadap kepuasan kerja.

$\mathrm{X}_{2} \rightarrow \mathrm{Y}_{1}=0,336$

c. Pengaruh variabel kompetensi terhadap kinerja.

$\mathrm{X}_{1} \rightarrow \mathrm{Y}_{2}=0,402$

d. Pengaruh variabel komunikasi organisasi terhadap kinerja.

$\mathrm{X}_{2} \rightarrow \mathrm{Y}_{2}=0,185$

e. Pengaruh variabel kepuasan kerja terhadap kinerja.

$\mathrm{Y}_{1} \rightarrow \mathrm{Y}_{2}=0,334$

3. Pengaruh Tidak Langsung (Indirect Effect atatu IE)

Untuk menghitung pengaruh tidak langsung atau IE, digunakan formula sebagai berikut:

a. Pengaruh variabel kompetensi terhadap kinerja melalui kepuasan kerja.

$\mathrm{X}_{1} \rightarrow \mathrm{Y}_{1} \rightarrow \mathrm{Y}_{2}=(0,440 \times 0,334=0,147)$ 
b. Pengaruh variabel komunikasi organisasi terhadap kinerja mellaui kepuasan kerja. $\mathrm{X}_{2} \rightarrow \mathrm{Y}_{1} \rightarrow \mathrm{Y}_{2}=(0,336 \times 0,334=0,112)$

\section{Pengaruh Total (Total Effect)}

a. Pengaruh variabel kompetensi terhadap kinerja melalui kepuasan kerja. $\mathrm{X}_{1} \rightarrow \mathrm{Y}_{1} \rightarrow \mathrm{Y}_{2}=(0,402+0,147=0,549)$

b. Pengaruh variabel komunikasi organisasi terhadap kinerja melalui kepuasan kerja. $\mathrm{X}_{2} \rightarrow \mathrm{Y}_{1} \rightarrow \mathrm{Y}_{2}=(0,185+0,112=0,297)$

\section{Diagram Analisis Jalur}

Diagram analisis jalur digunakan untuk membantu konseptualisasi masalah atau menguji hipotesis yang kompleks danjuga untuk mengetahui pengaruh langsung variabel langsung dan tidak langsung dari variabel bebas terhadap variabel terikat.

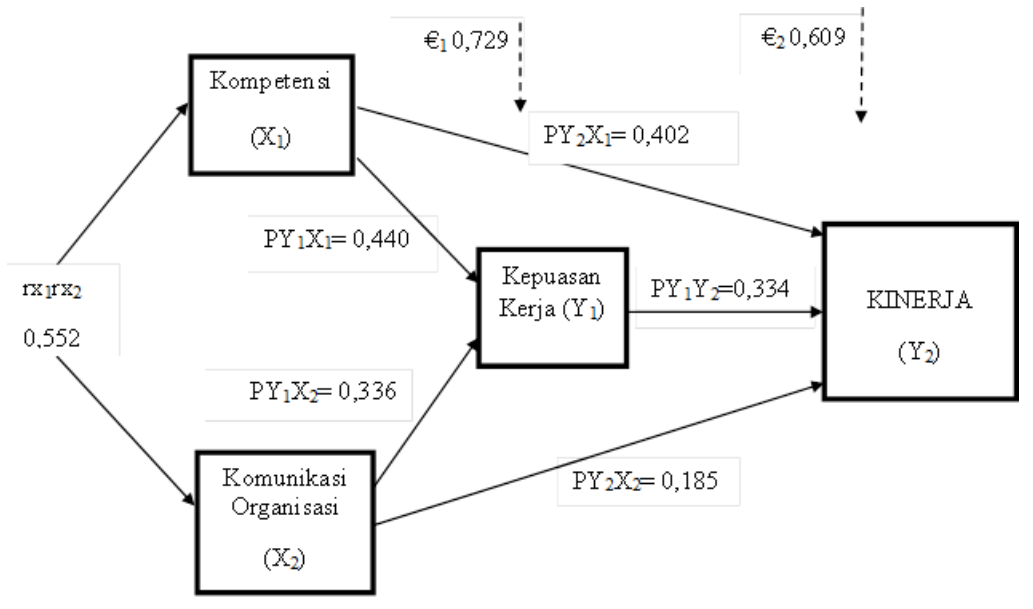

Gambar 5. Analisis Jalur

Berdasarkan gambar diagram jalur dapat dijelaskan bahwa variabel Kompetensi berpengaruh sebesar 0,440 terhadap kepuasan kerja, variabel komunikasi organisasi berpengaruh sebesar 0,336 terhadap kepuasan kerja, variabel kompetensi berpengaruh sebesar 0,402 terhadap kinerja, variabel komunikasi organisasi berpengaruh sebesar 0,185 terhadap kinerja dan variabel kepuasan kerja berpengaruh sebesar 0,334 terhadap kinerja.

\section{Uji sobel}

Dalam uji sobel digunakan untuk mengetahui pengaruh variebel mediasi yaitu kepuasan kerja.

\begin{tabular}{|c|c|c|c|c|}
\hline Input: & & Test statistic: & Std. Error: & $p$-value: \\
\hline a 0.544 & Sobel test: & 2.58427664 & 0.04841587 & 0.00975835 \\
\hline b 0.230 & Aroian test: & 2.53980411 & 0.04926364 & 0.01109146 \\
\hline sa 0.130 & Goodman test: & 2.63117025 & 0.04755299 & 0.00850914 \\
\hline$s_{b} 0.070$ & Reset all & \multicolumn{3}{|c|}{ Calculate } \\
\hline
\end{tabular}

\section{Gambar 6. Hasil Uji Sobel Struktural I}

Hasil uji sobel struktural I menunjukkan p-value atau signifikasi 0,0097<0,05. Hal ini menunjukkan bahwa variabel kompetensi berpengaruh terhadap variabel kinerja dengan 
kepuasan kerja sebagai variabel intervening. Artinya variabel kepuasan kerja berfungsi sebagai intervening dalam struktural I.

\begin{tabular}{|c|c|c|c|c|}
\hline Input: & & Test statistic: & Std.Error: & $\rho$-value: \\
\hline a 0.417 & Sobel test: & 2.28624741 & 0.04195084 & 0.02223979 \\
\hline b 0.230 & Aroian test: & 2.23351009 & 0.04294138 & 0.02551533 \\
\hline$s_{a} 0.131$ & Goodman test: & 2.34290597 & 0.04093634 & 0.0191342 \\
\hline$s_{b} 0.070$ & Reset all & & Calculate & \\
\hline
\end{tabular}

\section{Gambar 7. Hasil Uji Sobel Struktural II}

Hasil uji sobel struktural II menunjukkan p-value atau signifikasi 0,0222 < 0,05. Hal ini menunjukkan bahwa variabel komunikasi organisasi berpengaruh terhadap variabel kinerja dengan kepuasan kerja sebagai variabel intervening. Artinya variabel kepuasan kerja berfungsi sebagai intervening dalam struktural II.

\section{Pembahasan}

\section{Pengaruh Kompetensi Terhadap Kepuasan Kerja}

Pengujian hipotesis yang pertama untuk mengetahui pengaruh kompetensi terhadap kepuasan kerja. Berdasarkan hasil uji $\mathrm{t}$ diperoleh thitung sebesar 4,183 > ttabel 1,994 dengan tingkat signifikan sebesar 0,000 < 0,05. Hal ini mejelaskan bahwa Kompetensi berpengaruh positif dan signifikan terhadap kepuasan kerja.

2. Pengaruh Komunikasi Organisasi Terhadap Kepuasan Kerja

Pengujian hipotesis yang kedua untuk mengetahui pengaruh komunikasi organisasi terhadap kepuasan kerja. Berdasarkan hasil uji t diperoleh thitung sebesar 3,197 > ttabel 1,994 dengan tingkat signifikan sebesar 0,002 <0,05. Hal ini mejelaskan bahwa komunikasi organisasi berpengaruh positif dan signifikan terhadap kepuasan kerja.

3. Pengaruh Kompetensi Terhadap Kinerja

Pengujian hipotesis yang ketiga yaitu untuk mengetahui pengaruh kompetensi terhadap kinerja. Berdasarkan hasil uji $\mathrm{t}$ diperoleh thitung sebesar 4,052 > ttabel 1,994 dengan tingkat signifikan sebesar $0,000<0,05$. Maka dapat disimpulkan bahwa kompetensi mempunyai pengaruh positif dan signifikan terhadap kinerja.

4. Pengaruh Komunikasi Organisasi Terhadap Kinerja

Pengujian hipotesis yang keempat untuk mengetahui pengaruh komunikasi organisasi terhadap kinerja. Berdasarkan hasil uji $\mathrm{t}$ diperoleh thitung sebesar 1,947 < ttabel 1,994 dengan tingkat signifikan sebesar 0,056 >0,05. Hal ini dapat disimpulkan bahwa komunikasi organisasi tidak berpengaruh terhadap kinerja.

5. Pengaruh Kepuasan Kerja Berpengaruh Terhadap Kinerja.

Hipotesis kelima dilakukan untuk mengetahui pengaruh kepuasan kerja terhadap kinerja. Hasil ini menunjukan bahwa kepuasan kerja memiliki pengaruh terhadap kinerja yang ditunjukan dengan $t_{\text {hitung }}$ sebesar 3,289 $>t_{\text {tabel }} 1,995$ dengan tingkat signifikan,sebesar $0,002<0,05$. Maka dapat disimpulkan bahwa kepuasan kerja terbukti mempunyai pengaruh positif dan signifikan terhadap kinerja.

6. Pengaruh Kompetensi Terhadap Kinerja Melalui Kepuasan Kerja Sebagai Variabel Intervening. Hipotesis keenam dilakukan untuk mengetahui pengaruh kompetensi terhadap kinerja melalui kepuasan kerja sebagai variabel intervening. Dari hasil sobel test pada struktural I menunjukan bahwa test statistic $>$ ttabel yaitu 2,584 $>1,99495$ dan p-value $>$ a yaitu 0,009 < 0,05. Hal ini menunjukan bahwa variabel kepuasan kerja dapat memediasi kompetensi dan kinerja pada pendamping PKH di Kabupaten Kebumen. 


\section{Pengaruh Komunikasi Organisasi Terhadap Kinerja Melalui Kepuasan Kerja Sebagai Variabel Intervening.}

Hipotesis ketujuh dilakukan untuk mengetahui pengaruh komunikasi organisasi terhadap kinerja melalui kepuasan kerja sebagai variabel intervening. Dari hasil sobel test pada struktural II menunjukan bahwa test statistic $>$ ttabel yaitu 2,286 > 1,99495 dan p-value $>$ a yaitu 0,02 <0,05. Hal ini menunjukan bahwa variabel kepuasan kerja dapat memediasi komunikasi organisasi dan kinerja pada pendamping PKH di Kabupaten Kebumen.

\section{Penutup dan Saran}

Berdasarkan hasil penelitian menunjukan bahwa kompetensi berpengaruh positif dan signifikan terhadap kinerja melalui kepuasan kerja, bahwa pendamping PKH di Kabupaten Kebumen memiliki kemampuan, ketrampilan, dan pengetahuan yang baik dalam melaksanakan pekerjaanya. Oleh karena itu, untuk tetap mempertahankan kompetensi, organisasi dapat memberikan pelatihan dan pengembangan sehingga pendamping dapat meningkatkan kemampuan dan ketrampilan.

Berdasarkan hasil penelitian menunjukan bahwa komunikasi organisasi berpengaruh positif dan signifikan terhadap kinerja melalui kepuasan kerja. Oleh karena itu penulis menyarankan kepada pendamping PKH di Kabupaten Kebumen untuk meningkatkan komunikasi organisasi yang dapat dilakukan dengan memperjelas pemberian tugas baru kepada para pendamping agar tidak terjadi kesalahpahaman informasi dengan cara mengikutsertakan semua pendamping dalam pemeberian tugas. Dapat dilakukan melalui media daring seperti zoom dan google meet.

Berdasarkna hasil peneliian menunjukkan bahwa kepuasan kerja berpengaruh positif dan signifikan terhadap kinerja. Oleh karena itu, penulis menyarankn kepada pendamping PKH di Kabupaten Kebumen untuk memperhatikan kepuasan kerja pendamping agar kinerja yang dihasilkan pendamping lebih baik lagi. Upaya yang dapat dilalkukan untuk meningkatkn kepuasan kerja pendamping yaitu seperti memberikan fasilitas kerja yang lebih memadai dan memberikan reward atas pencapaian pendamping.

Berdasarkan hasil penelitian, kinerja adalah hasil kerja yang dapat dicapai oleh seseorang atau kelompok orang dalam satu organisasi sesuai dengan wewenang dan tanggungjawab masing-masing dalam upaya pencapaian tujuan organisasi. Kinerja pendamping dipengaruhi oleh faktor internal dan eksternal dari diri pendamping. Sehingga untuk meningkatkn kinerja, pendamping $\mathrm{PKH}$ perlu meningkatkan kompetensi, komunnikasi organisasi, dan kepuasan kerja.

\section{Referensi}

Afianto, I. D., \& Utami, H. N. (2017). Pengaruh Disiplin Kerja Dan Komunikasi Organisasi Terhadap Kepuasan Kerja Dan Kinerja Karyawan (Studi pada Karyawan Divisi Marketing PT. Victory International Futures Kota Malang). Jurnal Administrasi Bisnis, 50(6), 58-67.

Ardiansyah, D. O. (2016). Pengaruh Komunikasi Terhadap Kinerja Karyawan Dengan Dimediasi Oleh Kepuasan Kerja (Studi Pada Bagian Produksi Pabrik Kertas PT. Setia Kawan Makmur Sejahtera Tulungagung). Jurnal Bisnis dan Manajemen, 3(1). 
Arikunto, S. (2014). Prosedur Penelitian: Suatu Pendekatan Praktik. Jakarta: Rineka Cipta.

Fattah, H. (2017). Kepuasan Kerja dan Kinerja Pegawai: Budaya Organisasi, Perilaku Pemimpin, dan Efikasi Diri. Yogyakarta: Penerbit Elmatera (Anggota IKAPI)

Ghozali, I. (2011). Aplikasi Analisis Multivariate Dengan Program SPPS. Semarang: Badan Penerbit Universitas Diponegoro.

Hadi, N. (2011). Corporate Social Reponbility. Yogyakarta: Graha Ilmu.

Ikhsan, M., Reni, A., \& Hakim, W. (2019). Pengaruh Motivasi Kerja, Kompetensi dan Kompensasi terhadap Kinerja Agen melalui Kepuasan Kerja: Studi pada Prudential Life Assurance di Makassar. Hasanuddin Journal of Applied Business and Entrepreneurship, 2(1), 60-71.

Melani, T., \& Suhaji, S. (2012). Faktor-Faktor yang Mempengaruhi Kepuasan Kerja (Studi pada Karyawan Sekolah Tinggi Ilmu Farmasi" YAYASAN PHARMASI" Semarang). Jurnal Kajian Akuntansi dan Bisnis, 1(1), 103128.

Mendrofa, A. J., \& Syafii, M. (2019). Pola Komunikasi Organisasi dalam Meningkatkan Eksistensi Komunitas Marga Parna di Kota Batam (Studi Kasus Komunitas Marga Parna di Batu Aji Kota Batam). Scientia Journal: Jurnal Ilmiah Mahasiswa, 1(1).

Muhammad, A. (2019). Komunikasi Organisasi. Jakarta: Bumi Aksara.

Nazir, M. (2013). Metode Penelitian. Bogor: Ghalia Indonesia.

Pace, R. W., \& Faules, D. F. (2005). Komunikasi Organisasi. Bandung: PT. Remaja Rosdakarya.

Prasyanto, G. R. (2017). Pengaruh Kompetensi Karyawan terhadap Kinerja dengan Kepuasan Kerja sebagai Variabel Intervening (Studi pada PT. DOK dan Perkapalan Surabaya Bagian Produksi). Jurnal Ilmu Manajemen (JIM), 5(2).

Pratama, I. B. W., \& Sriathi, A. A. A. (2015). Pengaruh stres kerja dan pemberdayaan terhadap kepuasan kerja karyawan di Prama Hotel. E-Jurnal Manajemen, 4(11).

Program Keluarga Harapan (PKH). Diakses pada tanggal 27 Januari 2021, 15.02 WIB, dari https:// kemensos.go.id/program-keluarga-harapan-pkh

Putri, E. N., \& Ardiana, I. D. K. R. (2019). Pengaruh Motivasi Kerja, Kompetensi, dan Kompensasi Terhadap Kinerja Tenaga Kependidikan Melalui Kepuasan Kerja di Lingkungan ITS Surabaya. Management \& Accounting Research Journal, 3(2).

Rahadi, A., Suraida, I., \& Aisyah, I. S. (2016). Pengaruh Integritas Auditor dan Kompetensi Auditor Terhadap Kualitas Audit Internal (Studi kasus pada PT.Perkebunan Nusantara VII Bandung). Doctoral Dissertation. Perpustakaan Fakultas Ekonomi dan Bisnis Unpas Bandung.

Rokib, M. N., \& Santoso, D. (2018). Pengaruh gaya kepemimpinan partisipatif dan komunikasi organisasi terhadap kinerja karyawan melalui kepuasan kerja sebagai variabel intervening. Jurnal Riset Ekonomi dan Bisnis, 11(2), 108-127.

Saputra, A. T., Bagia, I. W., \& Yulianthini, N. N. (2016). Pengaruh kepuasan kerja dan loyalitas karyawan terhadap kinerja karyawan. Jurnal Manajemen Indonesia, 4(1). 
Sinambela, L. P., \& Sinambela, S. (2019). Manajemen Kinerja Pengelolaan, Pengukuran, dan Implikasi Kinerja. Depok: PT Rajagrafindo Persada.

Sudarmanto, S. (2018). Kinerja dan Pengembangan Kompetensi SDM. Yogyakarta: Pustaka Pelajar.

Sugiyono, S. (2010). Metode Penelitian Bisnis. Cetakan Kelimabelas. Bandung: Penerbit Alfabeta..

Wafa, M. A. (2019). Pengaruh Kerja Tim Terhadap Kepuasan Kerja Melalui Komitmen Organisasi sebagai Variabel Mediasi di AJB Bumiputera 1912 Cabang Darmo Satelit Surabaya. Jurnal Ilmu Manajemen (JIM), 7(1).

Wibowo, W. (2010). Manajemen Kinerja. Jakarta: Rajawali Pers. Edisi Ketiga. 